\title{
Landfill Temperatures Under Variable Decomposition Conditions
}

\author{
N. Yeşiller \\ J. L. Hanson \\ and $\mathrm{H}$. Yoshida
}

\begin{abstract}
This study was conducted to evaluate temperature, gas, and leachate data at two landfills in similar climatic regions (Detroit, Michigan, USA and Asahikawa, Hokkaido, Japan) to determine the interrelations between heat production and resulting waste temperatures and gas and leachate levels in landfills under variable decomposition conditions. Significant temperature increases occurred under longterm anaerobic conditions. Stable elevated temperatures under anaerobic conditions were observed for wastes at central locations. Seasonal fluctuations in both temperature and gas existed at shallow depths and near perimeter locations. Placement of an overfill of fresh wastes over old wastes affected temperatures, yet did not significantly influence existing anaerobic conditions. Temperatures increased at shallow depths and decreased at greater depths to reach the characteristic waste temperature profile observed in landfills located in temperate climates. Introduction of semi-aerobic conditions using passive gas vents resulted in high temperature variations. Heating and cooling were both observed, depending on vent location with a net heating effect of 1.3 to $3.0^{\circ} \mathrm{C}$ over 4 years. Temperatures of wastes below a leachate mound were low and varied less in comparison to wastes above the leachate mound under semi-aerobic conditions. Waste temperatures were lower above high leachate mound than low leachate mound.
\end{abstract}

\section{INTRODUCTION}

Significant amounts of heat are generated in MSW landfills due to the decomposition of the organic fraction of the waste mass. The heat generated results in long-term elevated waste temperatures with respect to local air and ground temperatures (Yeşiller et al. 2005, 2008). Heat generation is affected by operational and climatic conditions. In particular, maximum heat gain (temperature differential with respect to equivalent ambient conditions) in wastes is directly correlated to waste placement rates and initial waste temperatures and occurs at an optimum 
precipitation of approximately $2 \mathrm{~mm}$ /day with lower heat gain both below and above this level of precipitation (Yeşiller et al. 2005). In addition, heat generation rate in wastes is directly proportional to precipitation, daily air temperature, and waste placement rate and inversely proportional to waste density (Hanson et al. 2008).

Heat generation and development of elevated temperatures in wastes are coupled with generation and presence of gas and leachate in a waste mass through complex processes. Temperature, gas, and leachate data obtained in landfills in similar climatic regions in USA and Japan were investigated to determine the interrelations between waste temperatures and gas and leachate levels in landfills under variable decomposition conditions.

\section{FIELD SITES AND TEMPERATURE MONITORING}

Climatic and operational conditions for the two sites investigated in this study are presented in Table 1. The landfills are located near Detroit (Michigan USA) and Asahikawa (Hokkaido Japan), which have similar climatic conditions. These sites were selected to investigate the variation of temperatures with gas and leachate characteristics and decomposition conditions without the influence of climatic region.

Table 1. Climatic and Operational Conditions

\begin{tabular}{l|l|l}
\hline Parameter & \multicolumn{1}{|c|}{ Detroit $^{\mathrm{a}}$} & \multicolumn{1}{|c}{ Asahikawa $^{\mathrm{b}}$} \\
\hline Average air $T_{\text {high }}\left({ }^{\circ} \mathrm{C}\right)$ & 14.7 & 11.5 \\
\hline Average air $T_{\text {low }}\left({ }^{\circ} \mathrm{C}\right)$ & 5 & 1.6 \\
\hline Average air $T\left({ }^{\circ} \mathrm{C}\right)$ & 9.8 & 6.4 \\
\hline Mean surface $T\left({ }^{\circ} \mathrm{C}\right)$ & 11.8 & NA \\
\hline Surface $T$ amplitude $\left({ }^{\circ} \mathrm{C}\right)$ & 12.0 & NA \\
\hline Annual normal precipitation $(\mathrm{mm})$ & 835 & 1091 \\
\hline Annual normal snowfall (mm) & 1046 & 6340 \\
\hline Mean annual earth temperature $\left({ }^{\circ} \mathrm{C}\right)$ & 11.7 & NA \\
\hline Design waste placement area $($ ha) $)$ & 65 & 50 \\
\hline Average waste intake $(\mathrm{t} /$ year $)$ & 965,000 & 257,200 \\
\hline Average waste column height (m) & 25.2 & 14.8 \\
\hline Overall total unit weight $\left(\mathrm{kN} / \mathrm{m}^{3}\right)$ & $9-13$ & 8.5 \\
\hline Primary Daily Cover & Soil and & Soil \\
& demolition waste & \\
\hline
\end{tabular}

${ }^{a}$ from NCDC (2006), ${ }^{b}$ from Japanese Meteorological Agency (2010), NA = not available

The landfill located in Detroit is an active Subtitle D landfill with a liner system and gas and leachate collection systems. The Asahikawa landfill does not have a low permeability containment system. A leachate drainage network and gas vent pipes were installed at the site. The landfill was closed in 2003. Monitoring at the site indicated that the leachate collection system was not adequate to drain the leachate and significant mounding occurred within the landfill. In addition, groundwater infiltrated into the landfill due to a lack of a low permeability barrier system. The wastes were observed to be under anaerobic conditions based on the gas 
data collected during the monitoring events. A remediation plan was instated in 2004. Vertical wells and horizontal pipes were drilled into the waste mass to promote collection of the leachate to reduce the leachate mound. Vertical gas wells were drilled into the waste mass to re-introduce air into the waste mass to accelerate decomposition and stabilize the waste mass. Details of the remedial well designs are provided in Kim et al. (2009) and Kim et al. (2010).

Temperatures were measured in the Detroit landfill using dedicated horizontal and vertical thermocouple sensor arrays placed in the waste mass. The horizontal arrays allowed for determination of temperatures as a function of relative location at a given depth and the vertical arrays allowed for determination of temperatures as a function of waste depth and thus waste age. Gas concentrations also were measured at the same locations as the temperature measurements in both horizontal and vertical configurations using custom designed gas probes. Additional details of the temperature and gas measurement systems are provided in Yeşiller et al. (2005) and Hanson et al. (2010). The trenches and boreholes containing the sensors were sealed by either wastes or coarse-grained soils to prevent formation of voids or pathways in the waste mass that might have allowed movement of gas or liquid near the sensors. Such fluid movement may cause convective heat flow along the length of the arrays resulting in unrepresentative measurements. Temperatures at the Asahikawa landfill were measured by lowering thermocouple sensors into the vertical gas wells open to the atmosphere during specific monitoring events. Air and gas movement occur in the gas wells and the measured temperatures may not fully represent the adjacent waste mass temperatures at a given measurement location. Nevertheless, these temperature measurements provide representation of temperature trends and variations in temperatures due to changing decomposition conditions in the waste mass and were used in the analysis presented herein. Gas concentrations also were measured at the same locations as the temperature measurements in the gas wells using a portable gas analyzer. Additional details of the temperature and gas measurements are provided in Kim et al. (2009) and Kim et al. (2010).

Temperature and gas data have been obtained at the Detroit landfill since 1999. Temperatures were measured in wastes with a wide range of ages (newly placed wastes to over 20 year old wastes). Sensors placed in horizontal arrays during waste placement allowed for monitoring temperatures and gas levels from the day of placement in the landfills. Sensors placed in vertical arrays in areas that have reached terminal height allowed for monitoring temperatures and gas levels in older wastes. Temperature and gas data at the Asahikawa landfill have been obtained since 2005 in wastes with ages 2 years to over 20 years. Monitoring started with the installation of the remedial gas wells. The initial data set at each well represents temperature and gas conditions prior to the placement of the gas wells.

\section{LANDFILL TEMPERATURES}

Variations of temperatures and gas levels with time are presented for wastes placed at central, near-surface, and near-side locations of a cell at the Detroit site in Fig. 1. Similar trends were observed at additional comparable locations at the site. Temperatures as well as methane and carbon dioxide concentrations varied with 
seasonal fluctuations at near-surface and near-side locations (Fig. 1a, b), whereas less variation and steady trends were observed for wastes at the central location in the cell (Fig. 1c). At shallow depths, decomposition of wastes was inhibited during cold months of the year as indicated by low methane and carbon dioxide concentrations occurring at low temperatures. Temperatures reached levels that allowed for enhanced microbial activity, which resulted in higher methane and carbon dioxide concentrations in warm months. At the central location, gas composition changed over time, where the oxygen concentration decreased and methane and carbon dioxide concentrations started to increase. A peak is typically observed in $\mathrm{CO}_{2}$ concentration over a transition period from initial aerobic conditions. Subsequent to this period, the $\mathrm{CH}_{4}$ and $\mathrm{CO}_{2}$ concentrations stabilized at approximately $60 \%$ and $40 \%$, respectively indicating anaerobic decomposition conditions. Waste temperatures started to increase during the aerobic phase and continued to increase during all of the decomposition stages. Sustained steady elevated temperatures were measured in wastes under anaerobic conditions throughout the entire site. Temperature increase and heat gain were higher in the post-aerobic phase (i.e., cumulative transition and anaerobic phases) than the aerobic phase. Additional details for temperature increases in wastes under anaerobic conditions are presented in Yeşiller et al. (2005) and Hanson et al. (2010).
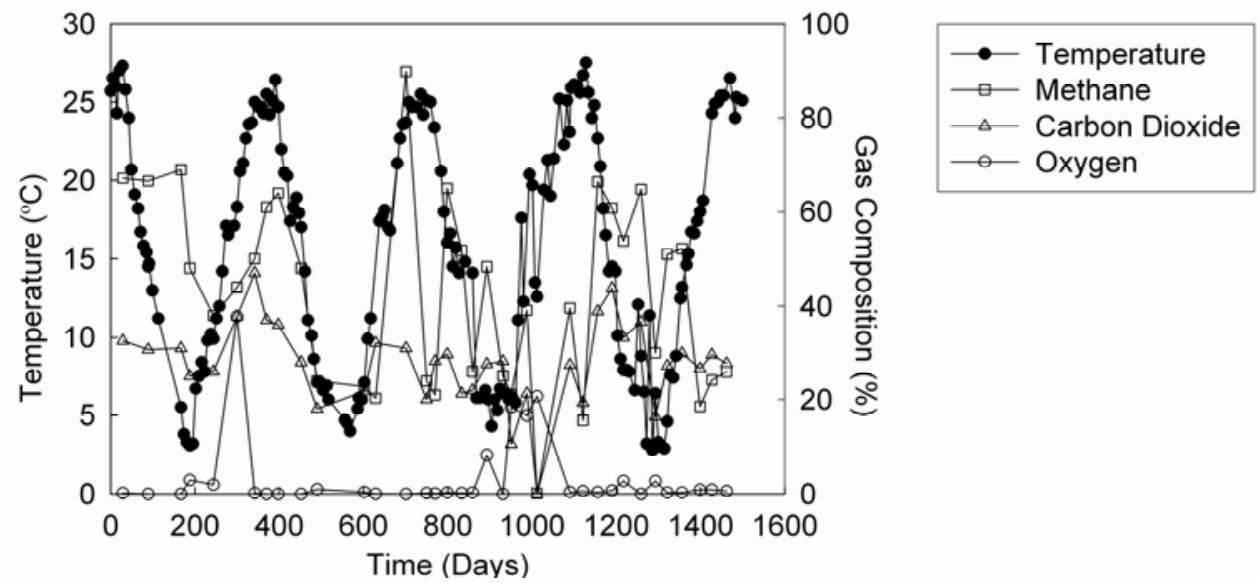

(a) Vertical array, Detroit (1 $\mathrm{m}$ depth)
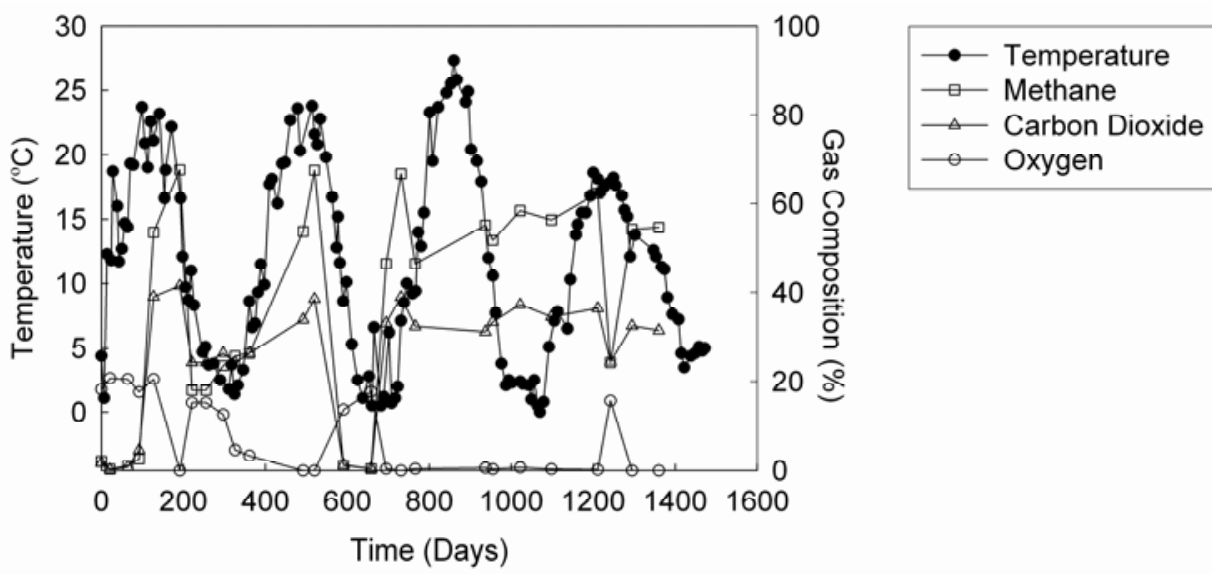

(b) Horizontal array, Detroit (2 m inside edge of cell) 


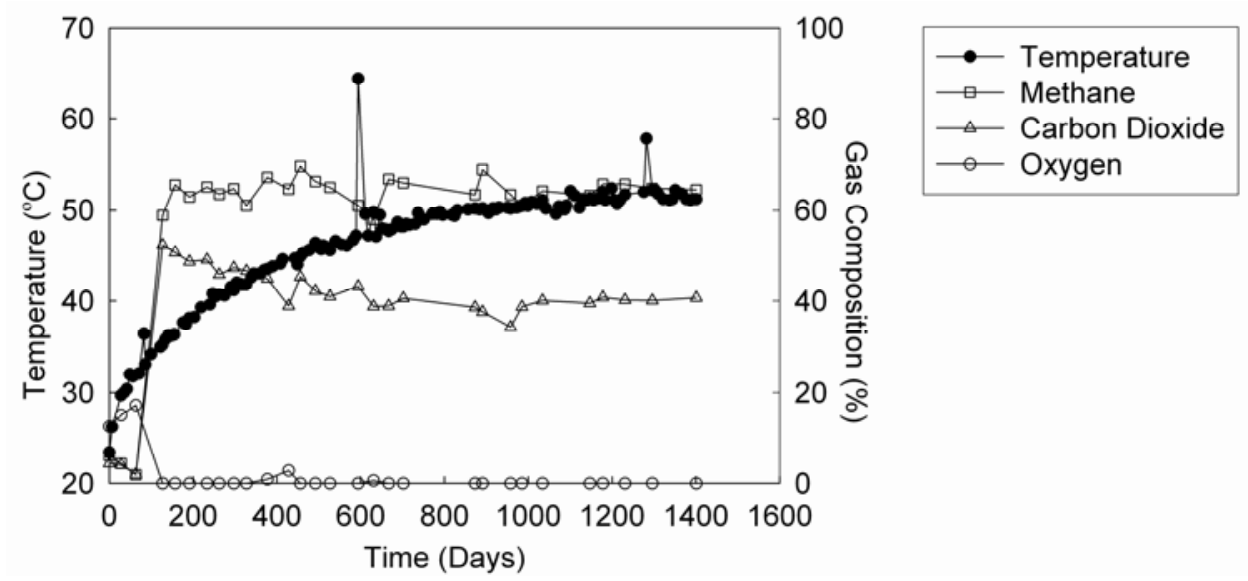

(c) Horizontal array, Detroit (100 m from edge, central depth)

Figure 1. Typical temperature-gas relationships in MSW landfills.

At the Detroit site, fresh wastes were placed over old wastes (7-8 year age) in a cell capped with a temporary cover. Variations of temperatures and gas levels in the cell prior and subsequent to placement of the fresh wastes are presented in Fig. 2. The fresh wastes were placed in two steps: 4-5 m (at Day 1725) and 3-4 m (at Day 2500). Anaerobic conditions prevailed at the measurement locations subsequent to placement of new wastes (Fig. 2). A low amount of air may have penetrated near the original shallow sensors (positive oxygen reading at Days 1725 and 2500).

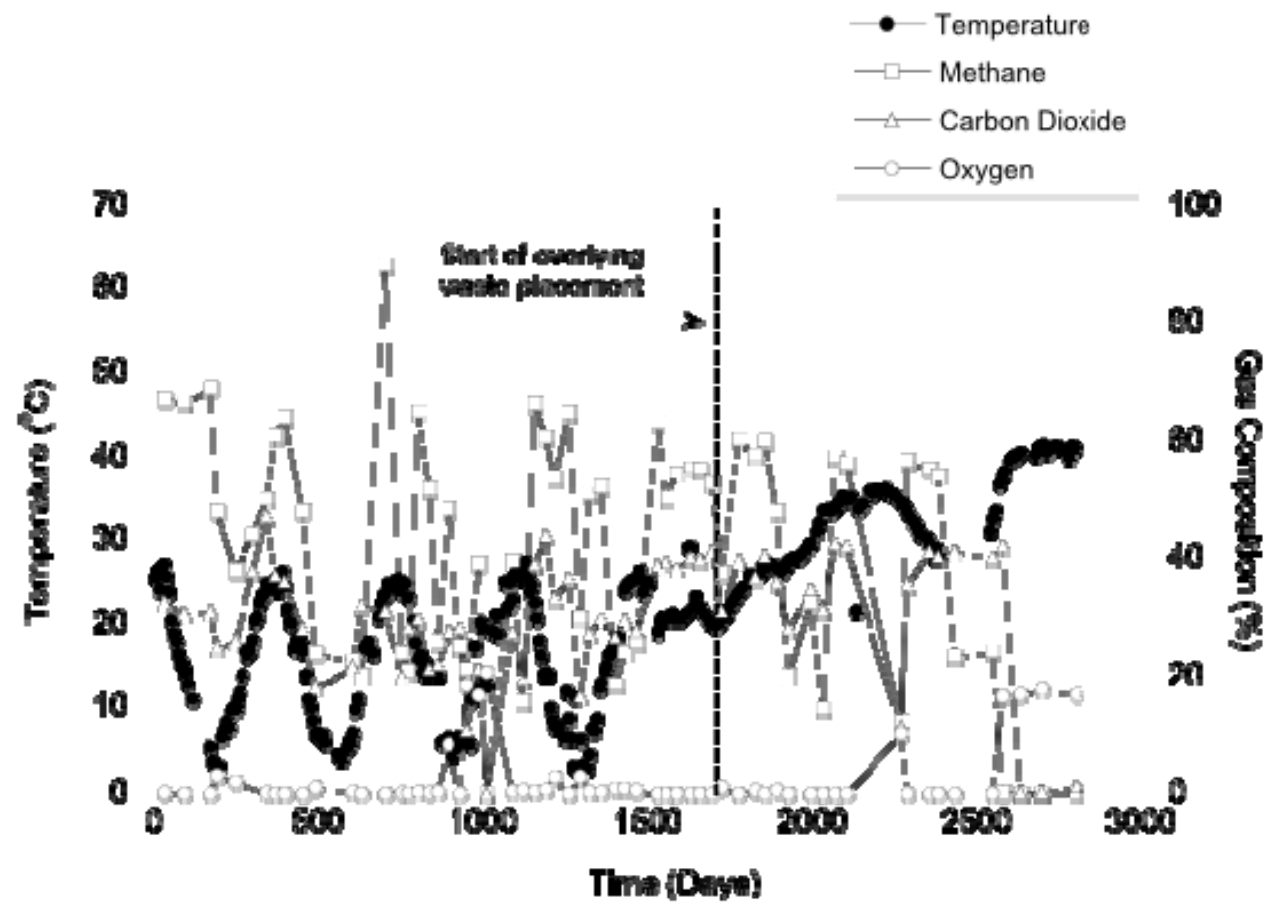

(a) Originally $1 \mathrm{~m}$ below surface 


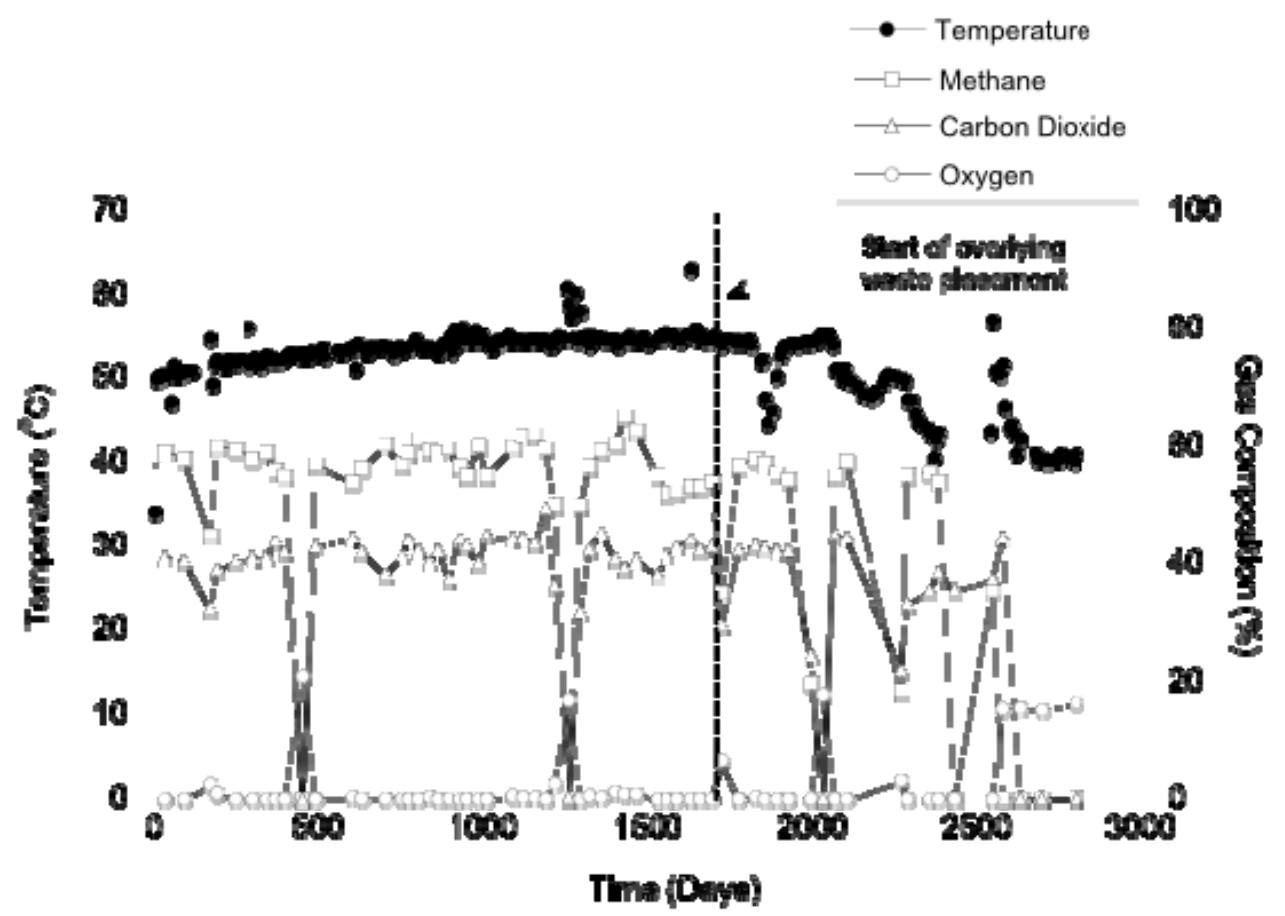

(b) Originally $12 \mathrm{~m}$ below surface

Figure 2. Temperature-gas relationships in MSW landfills due to overfilling.

The waste temperatures exhibited two distinct trends in response to the placement of the overlying fresh waste mass: temperatures at near surface locations increased by up to $20^{\circ} \mathrm{C}$ (Fig. 2a), whereas temperatures at center decreased by up to $15^{\circ} \mathrm{C}$ (Fig. 2b). The characteristic shape of waste temperature vs. depth relationship in temperate climates is a convex profile with maximum temperatures observed at central locations within the middle third fraction of the depth of a waste mass. Lower temperatures are observed above and below this central zone, with seasonal fluctuations occurring near the surface and steady and elevated values (above mean annual earth temperature) near the base of landfills (Hanson et al. 2010). The characteristic temperature profile was observed at the cell in Detroit with the maximum temperatures obtained at the central sensors at the middle of the cell and lower temperatures obtained at the shallow sensors near the surface. The relative locations of the sensors within the waste mass were altered due to the placement of the fresh waste layer where the shallow sensors became mid-depth sensors and the mid-depth sensors became deep sensors (below the middle third fraction of the depth of the waste mass). 
Therefore, the temperatures started increasing and decreasing at the original shallow and mid-depth sensors, respectively to reach the characteristic convex temperature profile (Fig. 3). The first profile in Fig. 3 represents conditions prior to overfilling. Supply of air as well as moisture, fresh organic matter, and bacteria from the new wastes promoted the increase in the temperatures at the original shallow sensors. Decreased proximity of the original mid-depth sensors to the centrally isolated hot zone in the waste mass subsequent to the placement of the fresh waste layer coupled with the reduced heat generation of the wastes of age 7 to 12 years around these sensors resulted in the decreased temperatures at depth.

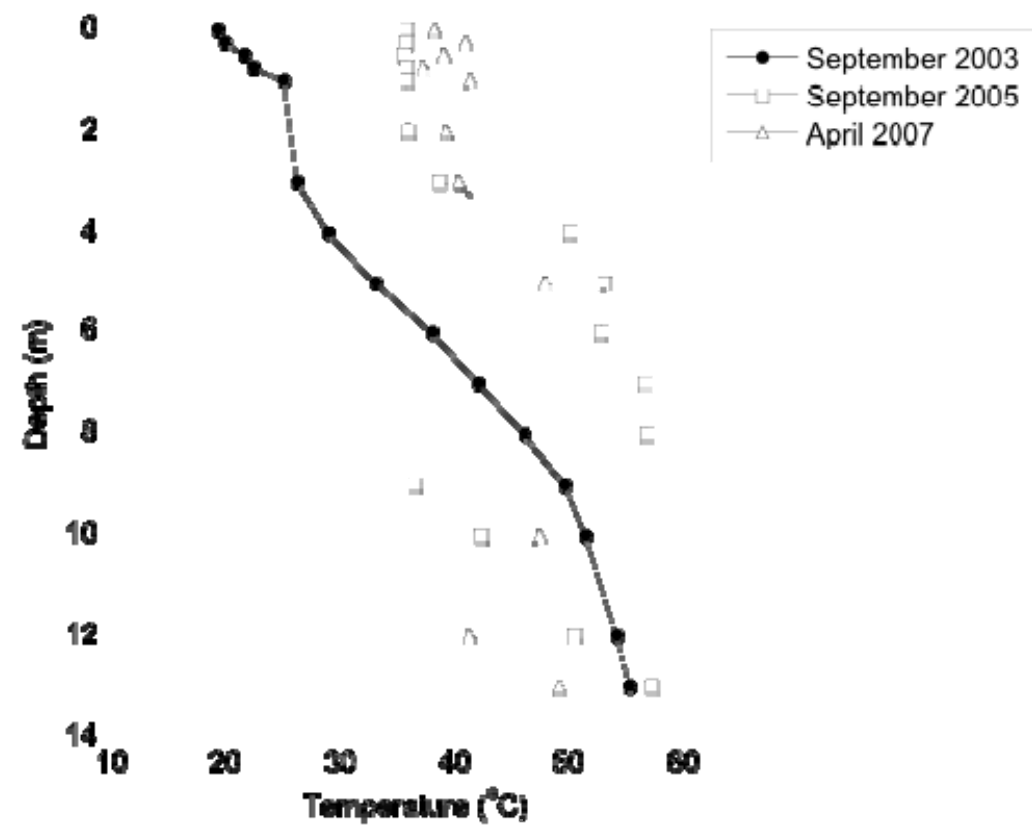

Figure 3. Variation of waste temperatures due to overfilling.

Temperatures and gas levels were analyzed for comparable locations at the Detroit and Asahikawa landfills. Temperatures were relatively steady with a slow increase from approximately 42 to $47^{\circ} \mathrm{C}$ for anaerobic wastes ( 5 to 9 year old, 5 to 10 $\mathrm{m}$ depth) over the 4-year measurement period at the Detroit landfill. Small seasonal fluctuations (temperature amplitude of approximately 2 to $3^{\circ} \mathrm{C}$ ) were observed at these depths. The initial temperatures at the Asahikawa landfill for similar wastes (approximately 7 to 12 year old age at 5 to $10 \mathrm{~m}$ depth) were approximately $33^{\circ} \mathrm{C}$ (ranging between 19 and $52^{\circ} \mathrm{C}$ ) under anaerobic conditions. Variations in the temperatures (both heating and cooling) occurred at the Asahikawa site due to introduction of air into the waste mass through the installation of the remedial gas wells. The semi-anaerobic conditions at the site resulted in final temperature changes (at the end of 4 years of semi-aerobic activity) as compared to starting anaerobic conditions that ranged between approximately $-4^{\circ} \mathrm{C}$ (net cooling) to $16^{\circ} \mathrm{C}$ (net heating) in the investigated zone (5 to $10 \mathrm{~m}$ depth). Overall, net heating was observed in 8 of the 12 wells at these depths and the average temperature increase was $4.7^{\circ} \mathrm{C}$. 
For the entire site in Asahikawa, the maximum temperatures (approximately $55^{\circ} \mathrm{C}$ ) were observed after approximately 2 years of semi-aerobic conditions and occurred over durations ranging from single survey measurements to several months, and in one case, 2 years. The temperatures in some wells decreased (to approximately 20 to $40^{\circ} \mathrm{C}$, depending on well) subsequent to an initial temperature rise, in many cases to levels below the initial temperatures at the onset of the gas vent installation. The passive gas vents allowed for convective movement of gases in the landfill system, where initial entry of air into the waste mass enhanced biological activity and caused increases in the waste temperatures. However, the high level of microbial activity could not be sustained with the system design and convective heat losses resulted in overall decreases in temperatures in the long term at some locations.

Variations of temperatures with depth are presented for a location with high leachate mound (approximately $26 \mathrm{~m}$ ) at the Asahikawa landfill in Fig. 4. The dashed lines in Fig. 4 indicate the elevations of the measured water table (upper dashed line) and top of the zone that demonstrated slower velocities of gas movement (lower dashed line), further described in Kim et al. (2009). Measurements were conducted to a limited depth into the leachate mound. For all measured wells above the leachate mound, temperatures varied significantly since the inception of semi-aerobic conditions: from $-12.8^{\circ} \mathrm{C}$ (net cooling) to $27.6^{\circ} \mathrm{C}$ (net heating). Overall, net cooling from starting temperatures was observed for $73 \%$ of the surveys, yet the average variation of measured temperatures from initial conditions was $3.0^{\circ} \mathrm{C}$ (net heating) for all measured wells above the leachate mound. The zone above the leachate mound had access to oxygen through convective flow and was at appropriate moisture conditions for active heat gain. The high temperature fluctuations were largely attributed to high convective currents in the well. Cyclic heating and cooling were observed throughout the height of the waste mass, which were not in phase or of similar period to seasonal air temperature fluctuations. In addition, analysis was conducted to compare waste temperatures over zones with low and high leachate mound at the site. The temperatures in wastes overlying low leachate mound were higher than the waste temperatures overlying high leachate mound. 


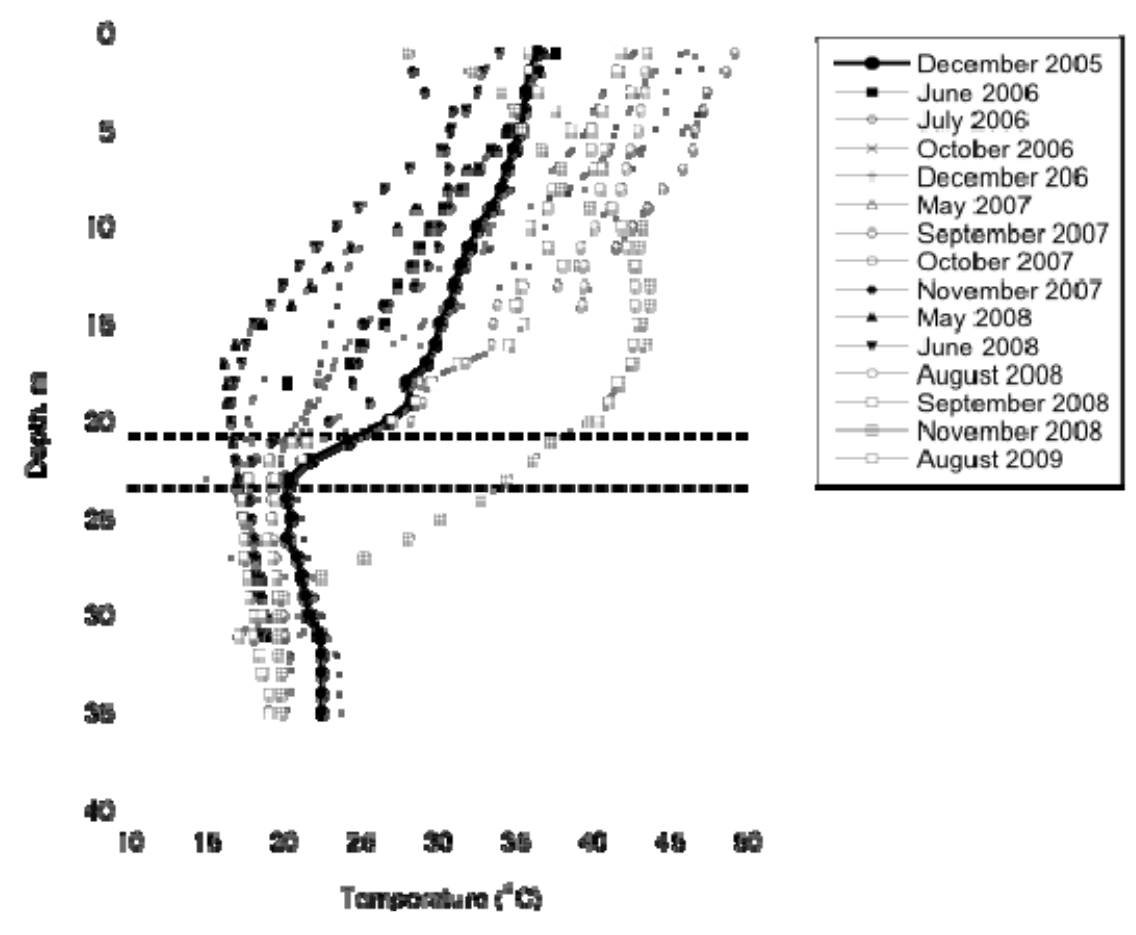

Figure 4. Variation of waste temperatures under semi-aerobic conditions.

For the zone within the leachate mound (i.e., below water table), temperatures remained relatively steady subsequent to onset of semi-aerobic conditions in the well (Fig. 4). For all measured wells within the leachate mound, temperatures varied from $-8.2^{\circ} \mathrm{C}$ (net cooling) to $28.8^{\circ} \mathrm{C}$ (net heating). Overall, net cooling from starting temperatures was observed for $58 \%$ of the surveys and the average variation of measured temperatures from initial conditions was $1.3^{\circ} \mathrm{C}$ (net heating) for all measured wells within the leachate mound. The zone within the leachate mound had limited access to oxygen due to the saturated or near-saturated conditions of the waste, and had significantly higher specific heat than overlying wastes due to the high moisture contents. Water has a much higher specific heat compared to the solid and gas components in the waste mass. Therefore, significantly higher heat generation is required to increase the temperature of wastes with high moisture content or below a leachate mound than drier wastes. Heat generation rate increases with moisture content, whereas an optimum level of moisture is present for maximum heat gain and associated maximum elevated temperatures beyond which heat gain and temperature increases decrease with increasing moisture content (Yeşiller et al. 2005, Hanson et al. 2008). Temperatures of unsaturated wastes (above leachate mound) were affected to a greater level by introduction of semi-aerobic conditions than saturated wastes (within the leachate mound). 


\section{CONCLUSIONS}

Heat generation and development of elevated temperatures in wastes are coupled with generation and presence of gas and leachate in a waste mass. Temperature, gas, and leachate data obtained in landfills in similar climatic regions in Detroit, Michigan, USA and Asahikawa, Hokkaido, Japan were investigated to determine the interrelations between waste temperatures and gas and leachate levels in landfills under variable decomposition conditions. The main conclusions of the study are:

- In conventional landfills, waste temperatures started to increase upon placement and continued to increase during all decomposition stages (aerobic, transition, and anaerobic). Sustained steady elevated temperatures were measured in wastes under anaerobic conditions. Temperature increase and heat gain were higher in the post-aerobic phase (i.e., cumulative transition and anaerobic phases) than the aerobic phase.

- Placement of an overfill of fresh wastes over old wastes affected temperatures in old wastes, yet did not significantly influence gas concentrations (generally existing anaerobic conditions remained). The temperatures in the old wastes were altered accordingly to reach the characteristic convex profile of waste temperature versus depth relationship subsequent to the placement of fresh wastes. Temperatures at near-surface locations of old wastes increased, whereas temperatures at the central locations of old wastes decreased due to overfilling.

- Introduction of air into old wastes under anaerobic conditions through passive gas vents resulted in increases in temperatures due to increased biological activity. The maximum temperatures (approximately $55^{\circ} \mathrm{C}$ ) were observed over periods ranging from a single measurement to months, and in one case, 2 years. The temperatures in some wells decreased (to approximately 20 to $40^{\circ} \mathrm{C}$ ) subsequent to an initial temperature rise, in many cases to levels below the initial temperatures at the onset of the gas vent installation. High level of microbial activity that started with installation of gas vents could not be sustained with the system design and convective heat losses resulted in overall decreases in temperatures in the long term. Overall, at the end of four years for all of the wells, the average variation of measured temperatures from initial conditions was net heating of 3.0 and $1.3^{\circ} \mathrm{C}$ for locations above and within the leachate mound.

- Temperatures and temperature variations at locations above zones with low leachate mound were generally higher than conditions at locations above zones with high leachate mound. Introduction of air into old wastes under anaerobic conditions with low leachate mound were more effective than air introduction into old wastes with high leachate mound. Waste temperatures below leachate mound were relatively low and remained low with changes in decomposition conditions. High specific heat of water inhibited changes in temperatures of high moisture content wastes. 


\section{ACKNOWLEDGEMENT}

This study was supported by the National Science Foundation (GOALI Grant: CMS-9813248 and SGER Grant: CMS-0301032). Assistance of the partner landfills, Sauk Trail Hills Development and Nakazono Landfill, are greatly appreciated.

\section{REFERENCES}

Hanson, J. L., Yeşiller, N., and Oettle, N. K. 2010. "Spatial and Temporal Temperature Distributions in Municipal Solid Waste Landfills." J. Envir. Engrg, 136(8), 1095-1102.

Hanson, J. L., Liu, W.-L., and Yeşiller, N. 2008. "Analytical and numerical methodology for modeling temperatures in landfills." Geotechnics of waste management and remediation, ASCE GSP No. 177, M. V. Khire, A. N. Alshawabkeh, and K. R. Reddy, eds., ASCE, Reston, Va., 24-31.

Japanese Meteorological Agency 2010. <http://www.jma.go.jp/jma/indexe.html> Accessed 20 May, 2010.

Kim, H. J., Endo, D., Sato, M., Matsuo, T., and Matsuto, T. 2009. "Estimation of water movement in a closed landfill based on tracer tests in gas vents and changes in leachate quality." Waste Manage., 29, 2308-2315.

Kim, H. J., Yoshida, H., Matsuto, T., Tojo, Y., and Matsuo, T. 2010. "Air and landfill gas movement through passive gas vents installed in closed landfills." Waste Manage., 30, 465-472.

NCDC. 2006. "Climate database," National Climatic Data Center, http://www.ncdc.noaa.gov/ Accessed: 15 September 2006.

Yeşiller, N., Hanson, J. L., and Liu, W.-L. 2005. "Heat generation in municipal solid waste landfills." J. Geotech. Geoenviron. Eng., 131(11), 1330-1344.

Yeşiller, N., Hanson, J. L., Oettle, N. K., and Liu, W.-L. 2008. "Thermal analysis of cover systems in municipal solid waste landfills." J. Geotech. Geoenviron. Eng., 134(11), 1655-1664. 